Journal of Health Policy and Management (2019), 4(2): 86-90

https://doi.org/10.26911/thejhpm.2019.04.02.02

\title{
Association between Socialization and the Use of Maternity Waiting Home in East Aceh, Indonesia
}

\author{
Atika Triwulan Dari, Zulfendri, Destanul Aulia
}

Masters Program in Public Health, Universitas Sumatera Utara

\begin{abstract}
Background: Maternity waiting homes are residential facilities where women who live remotely can wait before giving birth at a hospital or health centre. The aim of implementing a maternity waiting home strategy is to reduce maternal and perinatal mortality by improving access to skilled birth attendance and emergency obstetric care, particularly for women in rural and remote areas. This study aimed to examine the association between socialization and the use of maternity waiting home in East Aceh.

Subjects and Method: This was a cross-sectional study carried out at four community health centers (puskesmas), in East Aceh, Indonesia. A sample of 130 pregnant mothers was selected for this study by stratified random sampling. The dependent variable was the use of maternity waiting home. The independent variable was socialization and family support. The data were collected by questionnaire and analyzed by a multiple logistic regression.

Results: Socialization was associated with an increased use of maternal waiting home (OR=14.17; $\mathrm{p}=0.002$ ), after controlling from the effect of family support.

Conclusion: Socialization is associated with an increased use of maternal waiting home, after controlling for the effect of family support.
\end{abstract}

Keywords: maternity waiting home, socialization, family support.

\section{Correspondence:}

Atika Triwulan Dari. Masters Program in Public Health, Universitas Sumatera Utara, Jalan Universitas No. 21, Universitas Sumatera Utara, Medan 20155, North Sumatera, Indonesia. Email: atika.triwulandari@ymail.com.

\section{BACKGROUND}

Based on the results of the Indonesian $\mathrm{He}-$ alth Demographic Survey (IDHS) in 2012, the average maternal mortality rate jumped to 359 per 100,000 live births (Indonesian Ministry of Health, 2014). The live births are based on the results of the 2015 Intercensal Population Survey (SUPAS) (Indonesian Ministry of Health, 2017).

In an effort to reduce the Maternal Mortality Rate, the government through the Ministry of Health of the Republic of Indonesia since 1990 has launched a safe motherhood initiative, which is a program that ensures all women get the care needed so that they are safe and healthy during pregnancy and childbirth. The effort was continued with the Dear Mother Movement program in 1996 by the President of the Republic of Indonesia. This program involves other sectors outside of health. One of the main programs aimed at overcoming the problem of maternal mortality is the placement of midwives at the village level on a large scale which aims to bring closer access to maternal and newborn health services to the community (Ministry of Health, 2017). But until now its existence in every village is still being sought. One effort to reach pregnant women in difficult geographical areas to health services and to optimize the use of midwives is the maternity waiting home program $(\mathrm{MOH}$, 2009). 
Maternity waiting home are places that are near health facilities (hospitals, health centers, health posts) and are used as temporary housing for pregnant women and their companions, while waiting for labor to arrive and several days after delivery (Ministry of Health, 2009). According to Permenkes No. 82 In 2015 the maternity waiting home is an effort to bring access closer and prevent delays in treatment for pregnant women, mothers of childbirth, and newborns, especially in areas where access to health facilities is difficult.

The purpose of maternity waiting homes is to increase the coverage of deliveries that are assisted by health personnel and carried out in health care facilities and to improve the detection and early treatment of maternal complications, which in turn can play a role in accelerating the reduction of Maternal Mortality Rate (MMR).

East Aceh Regency is a district in Aceh Province with a high number of maternal deaths. Based on data from the East Aceh District Health Office in 2015, the number of maternal deaths was recorded as 14 cases per 8,430 live births, 624 cases of childbirth were carried out opened by health service facilities and 117 cases of childbirth were still assisted by other health personnel. The cause of the highest maternal mortality was caused by obstetric complications such as bleeding in 9 cases, 2 cases of hypertension in pregnancy, 3 cases of infection, those who received immediate emergency care by health personnel.

The geographical conditions of Aceh Regency are generally in the lowlands, hills, parts of swamps and mangrove forests. In his interview, the Deputy District Head of East Aceh stated that dozens of villages in a number of sub-districts in East Aceh Dis- trict were still lagging and remote. The distance between the village and the health center is 30 kilometers away. On the other hand, transportation access to several subdistrict capitals must be taken within 5-8 hours of land travel and even river transportation. The road is located in several sub-districts which are severely damaged even up to 45 kilometers even though road repairs are carried out every year. Even if high rainfall, it causes some road access in East Aceh Subdistrict to be like mud puddles until it is totally paralyzed (Ali, 2017). Such conditions are one of the factors causing delays in maternity management such as cases of maternal death due to invertio frowning on the life of a mother from Peunaron sub-district, East Aceh.

\section{SUBJECTS AND METHOD}

This was a cross sectional study conducted at Peureulak Kota, Nurussalam, Rantau Selamat, and Indra Makmur community health centers. A sample of 130 pregnant women was selected by stratified random sampling. The dependent variable was utilization of maternity waiting home. The independent variables were husband/family support and socialization of maternity waiting house. The data were collected by questionnaire. The data were analyzed by a multiple logistic regression.

\begin{tabular}{l}
\hline RESULTS \\
1. Univariate analysis \\
Table 1 showed the results of univariate \\
analysis. Table 1 showed that the majority \\
of mothers had weak family support \\
$(61.5 \%)$, poor socialization of maternity \\
waiting home (56.9\%), and most of them \\
did not use maternity waiting house \\
$(73.1 \%)$.
\end{tabular}


Journal of Health Policy and Management (2019), 4(2): 86-90

https://doi.org/10.26911/thejhpm.2019.04.02.02

Table 1. The Distribution of Sample Characteristics

\begin{tabular}{lcc}
\hline \multicolumn{1}{c}{ Independent Variables } & n & \% \\
\hline Family Support & 50 & 38.5 \\
Strong & 80 & 61.5 \\
Weak & & \\
Socialization of Maternity Waiting Home & 56 & 43.1 \\
Good & 74 & 56.9 \\
Poor & & \\
Use of the Maternity Waiting House & 35 & 26.9 \\
Utilizing & 95 & 73.1 \\
Not utilizing & & \\
\hline
\end{tabular}

\section{Bivariate anaysis}

Table 2 showed the results of bivariate analysis. Table 2 showed the utilization of maternity waiting home decreased with weak family support $(\mathrm{OR}=0.15 ; \mathrm{p}<0.001)$ and poor socialization of maternity waiting home $(\mathrm{OR}=0.12 ; \mathrm{p}<0.001)$.

\section{Table 2. Bivariate analysis results}

\begin{tabular}{|c|c|c|c|c|c|c|c|c|}
\hline \multirow{3}{*}{ Variable } & \multicolumn{4}{|c|}{$\begin{array}{c}\text { The Utilization of Maternity } \\
\text { Waiting Home }\end{array}$} & \multirow{2}{*}{\multicolumn{2}{|c|}{ Total }} & \multirow{3}{*}{ OR } & \multirow{3}{*}{$\mathbf{p}$} \\
\hline & \multicolumn{2}{|c|}{ Yes } & \multicolumn{2}{|c|}{ No } & & & & \\
\hline & $\mathbf{n}$ & $\%$ & $\mathbf{n}$ & $\%$ & $\mathbf{n}$ & $\%$ & & \\
\hline Family Support & & & & & & & & \\
\hline Strong & 28 & 56.0 & 22 & 44.0 & 50 & 100 & 0.15 & $<0.001$ \\
\hline Weak & 7 & 8.8 & 73 & 91.2 & 80 & 100 & & \\
\hline $\begin{array}{l}\text { The socialization } \\
\text { of Maternity }\end{array}$ & & & & & & & & \\
\hline Good & 30 & 53.6 & 26 & 46.4 & 56 & 100 & 0.12 & $<0.001$ \\
\hline Poor & 5 & 6.8 & 69 & 93.2 & 74 & 100 & & \\
\hline
\end{tabular}

Table 3. The Results of Multiple Logistic Regression Analysis

\begin{tabular}{lcc}
\hline \multicolumn{1}{c}{ Variable } & OR & p \\
\hline Maternity waiting home socialization & 14.17 & $<0.001$ \\
Family support & 8.39 & $<0.001$ \\
Constant & 0.17 & $<0.001$ \\
\hline
\end{tabular}

\section{DISCUSSION}

1. The relationship of family support on the use of materity waiting home

Husband/family support have an important role in choosing helpers during pregnancy, childbirth, and postpartum. Friedman (2000) stated that husband/ family support was a gesture of action and family accept-

\section{Multivariate analysis}

Table 3 showed the results of multiple logistic regression analysis that

did not use maternity waiting houses amounting to 95 respondents (73.1\%) compared to 35 respondents (26.9\%) who used maternity waiting houses. 
According to Friedman (2000), husband/family support was an attitude of action and family acceptance of sufferers who were sick. The family also functioned as a support system for its members and family members view that people who were supportive were always ready to provide help with assistance if needed. Based on the results of the study, it was found that weak husband/ family support decreased the use of maternity waiting home.

The result of this study was in line with Mardiyah (2013) which showed that there was a significant relationship between family support and utilization of antenatal health services by pregnant women at Tempurejo community health center in Jember, East Java.

Husband/family support has an important role in decision of birth delivery place. They argued that husband or family decisions were the best because parents were more experienced than they were. In addition, if they follow the advice of their parents and if something bad happens, then the whole family and especially the parents would take responsibility. In addition, with the husband/family support, the mother did not have to worry to leave the house and children because there were those who looked after and took care of everything.

\section{The relationship of maternity wait- ing home socialization and the use of maternity waiting homes}

Socialization of maternity waiting homes was one of the steps taken by the Indonesian government in an effort to increase the coverage of deliveries assisted by health personnels in health care facilities, as well as to improve the detection and early treatment of maternal complications.

The results of the study showed that mothers at the East Aceh District community health center had the were mostly got poor socialization of maternity waiting homes (56.9\%).

The socialization of the maternity waiting home program was very necessary to provide information to the general public about the benefits and advantages of maternity waiting homes. The credibility of socialization of maternity waiting home was an important factor in the successful utilization of the maternity waiting home itself.

Based on the results of the study, good socialization of maternity waiting home increased the use of maternity waiting home. This showed that pregnant women with good socialization of maternity waiting house was 14.17 times more likely to use maternity waiting homes.

The results of this study was in line with Anggraeni (2012), which stated that there was a significant relationship between socialization of maternity waiting home and health services use in Tanah Laut, Kalimantan, Indonesia. Socialization of maternity waiting house increased maternal knowledge about the purpose and benefits of the maternity waiting house home.

\begin{tabular}{l}
\hline REFERENCE \\
\hline Ali Z (2017). Pemerintah pusat diminta \\
perhatikan pedalaman Aceh Timur, \\
diakses 16 November 2017; http://- \\
klikkabar.com. \\
Anggraeni S (2012). Analisis faktor-faktor \\
yang berpengaruh terhadap peman- \\
faatan pelayanan kesehatan (PKPR) \\
di wilayah Puskesmas Kabupaten \\
Tanah Laut Kalimantan Selatan. (Jur- \\
nal Elektronik) diakses 22 Juni 2018; \\
http://eprints.undip.ac.id. \\
Depkes RI (2009). Pedoman pelayanan \\
rumah tunggu kelahiran. Jakarta: \\
Direktorat Jendral Bina Program \\
Kesehatan Masyarakat.
\end{tabular}


Journal of Health Policy and Management (2019), 4(2): 86-90

https://doi.org/10.26911/thejhpm.2019.04.02.02

Friedman M (2000). Keperawatan Keluarga, Teori DanPraktek. Alih Bahasa: Ina Debora: Edisi 3. Jakarta : EGC.

Kemenkes RI (2014). Mother's Day, Jakarta: Pusat Data Dan Informasi Kementrian Kesehatan RI.

(2017). Profil Kesehtan Indonesia Tahun 2016.
Mardiyah U (2013). Faktor yang berhubungan dengan pemanfaatan pelayanan antenatal oleh ibu hamil di wilayah kerja puskesmas Tempurejo Kabupaten Jember. (Jurnal Elektronik) diakses 22 Juni 2018; http://jurnal.unej.ac.id. 